\title{
New hosts and parasitism notes for the mite Leptus (Acari: Erythraeidae) in fragments of the Atlantic Forest, Brazil
}

Pereira, AIA. ${ }^{a}$, Fadini, MAM. $^{b *}$, Pikart, TG. $^{a}$, Zanuncio, JC. ${ }^{a}$ and Serrão, JE. ${ }^{c}$

${ }^{a}$ Departamento de Biologia Animal - DBA, Universidade Federal de Viçosa - UFV, CEP 36571-000, Viçosa, MG, Brazil

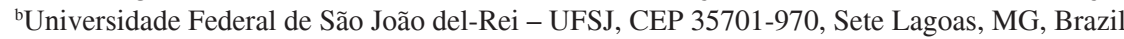

'Departamento de Biologia Geral, Instituto de Biotecnologia Aplicada à Agropecuária - BIOAGRO,

Universidade Federal de Viçosa - UFV, CEP 36571-000, Viçosa, MG, Brazil

*e-mail: fadini@ufsj.edu.br

Received July 6, 2011 - Accepted September 12, 2011 - Distributed August 31, 2012

(With 2 figures)

\begin{abstract}
New hosts and parasitism notes for the mite Leptus (Acari: Erythraeidae) in Brazil. Larval erythraeid mites are common ectoparasites of harvestmen (Opiliones). Studies describing insects as potential hosts have received little attention. Specimens of an undescribed species of the genus Leptus were collected in association with predatory and phytophagous Heteroptera bugs in a secondary forest in Viçosa, Minas Gerais state, Brazil. New mite-host records and information on seasonality of this mite are presented.
\end{abstract}

Keywords: Heteroptera, host, parasite, predatory bugs.

\section{Novos hospedeiros e notas sobre o parasitismo do ácaro Leptus (Acari: Erythraeidae) em fragmento de Mata Atlântica, Brasil}

\section{Resumo}

Há novos hospedeiros e notas sobre o parasitismo do ácaro Leptus (Acari: Erythraeidae) no Brasil. As larvas de ácaros da família Erythraeidae são ectoparasitas comuns de opiliões (Opiliones). Estudos de insetos como potenciais hospedeiros de ácaros eritraídeos são escassos. Indivíduos de uma espécie nova do gênero Leptus foram coletados em associação com percevejos fitófagos e predadores (Heteroptera) em uma floresta secundária no município de Viçosa-Minas Gerais, Brasil. São apresentadas informações sobre a sazonalidade e o registro de hospedeiro desse ácaro do gênero Leptus.

Palavras-chave: Heteroptera, hospedeiro, parasita, percevejos predadores. 


\section{Introduction}

Several taxonomic groups of mites parasitize arthropods. The mites belonging to the large and cosmopolitan genus Leptus Latreille 1796 (Erythraeidae) are parasitic as larvae using a wide range of arthropods to feed (Welbourn, 1983). This interspecific relationship has a range of ages (from Eocene) and it has been proved due to a huge number of Leptus mite species preserved as amber fossils (Arillo, 2007). Mite larvae pierce the cuticle of the host and ingest hemolymph and interstitial fluids via a stylostome, or not (Âbro, 1988), which acts as a proteinaceous drinking straw. After engorging, larvae drop off the host and transform into octopod nymphs and adults which are free-living, predatory deutonymphs.

At least, six of the 11 extant orders of Arachnida (Acari, Araneae, Amblypygi, Opiliones, Pseudoscorpiones and Scorpiones) are formed by potential hosts (Baker and Selden, 1997; Armas and Pietro Trueba, 2003; Southcott, 2008) and most of them consist of Opiliones, Leiobunum spp. (harvestmen) which has been the subject of much study. Cokendolpher (1993) listed 18 species of Leptus, whose parasitic larvae has been found attached to Opiliones in North America. On the other hand, the number of insects potentially parasitized by Leptus spp. mites is still underestimated. Prior studies have registered pollinators (Fletchtmann, 1980; Southcott, 1993), social insects (Eickwort, 1990), phytophagous pests (Haitlinger, 1993, 1999, 2009; Saboori and Ostovan, 2000; Coracini and Samuelis, 2002) and specific insect groups such as diptera (Southcott, 1991), noctuid and geometrid moths (Southcott, 1992) as adequate hosts.

Although mites are assumed to feed upon hemolymph, little is known about the impact of erythraeid parasitic mites on the life history of their hosts in tropic environments. This work focuses on terrestrial Heteroptera, which are important components in the balance of natural food webs and may be as vulnerable as other groups of insects and arachnids. Therefore, the objective was to describe the presence of Leptus sp. in predators and phytophagous species of Heteroptera insects and relate the mite parasitism frequency through a three-year period using field observations.

\subsection{Material and Methods}

The study was conducted in a 20 ha fragment of secondary forest (semideciduous seasonal forest) at the Department of Animal Biology at the Federal University of Viçosa (UFV) in Viçosa, Minas Gerais State, Brazil at $20^{\circ} 45^{\prime} \mathrm{S}$ and $42^{\circ} 51^{\prime} \mathrm{W}$, at an altitude of $651 \mathrm{~m}$. This area has native and exotic species, including Psidium guajava, Psidium catleianum and Eucalyptus spp. (Myrtaceae), as well as other arboreal and herbaceous plants with a floristic pattern similar to that described by Marangon et al. (2003). The mean annual temperature ranges from $14.6{ }^{\circ} \mathrm{C}$ to $21.8^{\circ} \mathrm{C}$ and the mean annual rainfall is $1,220 \mathrm{~mm}$.

Sweeping vegetation was sampled through an entomological vacuum glass $(150 \mathrm{~mL})$. The area where the samples were carried out was limited by two transects to reduce variation of factors such as topography and soil type (Zanuncio et al., 2004; Reis et al., 2008). These transect lines had a range of plant species such as broadleaves, shrub species, ground vegetation and tree plants (Lapola and Fowler, 2008). Each transect was $200 \mathrm{~m}$ long by $20 \mathrm{~m}$ wide, with an area sampled of $8000 \mathrm{~m}^{2}$. The collector initially crossed the plot, making a path of recognition. After this, each route was walked slowly in the morning from 09:00 AM until 12:00 AM, especially considering the road itself and their sides. The time of collection was chosen due to the peak of insects foraging activity throughout the day. A total of ten samples were taken in the summer seasons due to the high abundance of bugs in the field (AIAP, personal observations) in 2007, 2008 and 2009.

Each individual was carefully examined with a stereomicroscope and the number of mites attached to each individual was recorded. Then, the mite parasitism (fraction of individuals infested) and intensity of mite infestion (mean number of mites per infested individual) were recorded (McAlonn and Durden, 2000). Voucher specimens of Leptus sp. and all bugs collected were transferred to the Laboratory of Biological Control of the Institute of Biotechnology Applied to Agriculture (BIOAGRO) where they were quantified, photographed and stored in $70 \%$ ethanol. Mite specimens were mounted in Hoyer's medium on slides and sent to a specialist in that mite group for identification.

\section{Results}

102 adults and seven nymphs of Heteroptera were captured in the whole experimental period. A total of 12 mites of an undescribed species were sampled in the survey, with 11 specimens of bugs observed as hosts. Only one mite was found in 2007 on a pentatomid bug, three mites were found in 2008 (two on pentatomids and one on reduviid) and in the summer of 2009, three mites were found on pentatomids and five on reduviids, with two mites present on the same individual host (Figure 1). The mite parasitism varied from 0.02 in the summer of 2007 to 0.11 and 0.14 in 2008 and 2009, respectively, while the intensity of mite infestation throughout the years was 1, 1 and 1.14 , respectively. There was a difference in the mite infestation between the experimental period $\left(\chi^{2}=6.50\right.$, $d f=2, P=0.03)$ with mite infestation more prevalent in the summer of 2009 than in the summer of $2007\left(\chi^{2}=5.44\right.$, $d f=1, P=0.01)$ and $2008\left(\chi^{2}=6.22, d f=1, P=0.02\right)$.

A total of four genera for the family Reduviidae and three for Pentatomidae were found in the experimental period (Table 1). The Heteroptera species found as hosts of Leptus sp. were the reduviids Heza sp. and Apiomerus sp. and the pentatomids Edessa sp.1 (adults and nymphs) and Edessa sp.2 (Figure 2). The mite was not aggregated on individual reduviid or pentatomid hosts and attached to specific areas of the host integument such as between rows of stout setae, near or on the scutellum. In one case, a mite was attached to the ventral side of the nymph abdomen (Figure 2). No mites were observed on body segments of the bugs such as femur, tibia or tarsus. 


\section{Discussion}

The dorsal part of the bugs was preferred by the mites to attach with a similar pattern showed by Baker (1982) on passalid beetles. Some authors believe that there is no evidence of host attachment site preferences by Leptus spp. (Baker, 1982; Wendt et al., 1992). However, McAloon
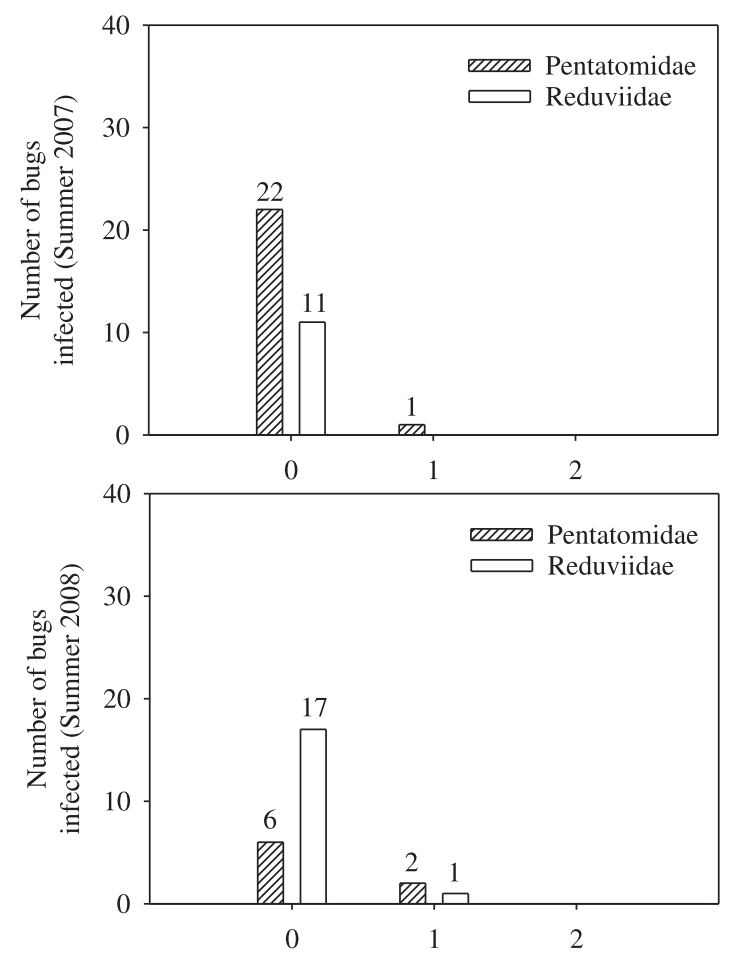

Mites present per individual and Durden (2000) demonstrated that Leptus indianensis (Acari: Prostigmata) preferred to attach on the femur of the harvestmen Leiobunum formosum (Opiliones) which may be in response to avoid antagonist behavior by the host attempting to deter or dislodge parasites. This seems not fit for bugs which constantly use their legs to clean themselves, for example after predation (Lemos et al., 2005)
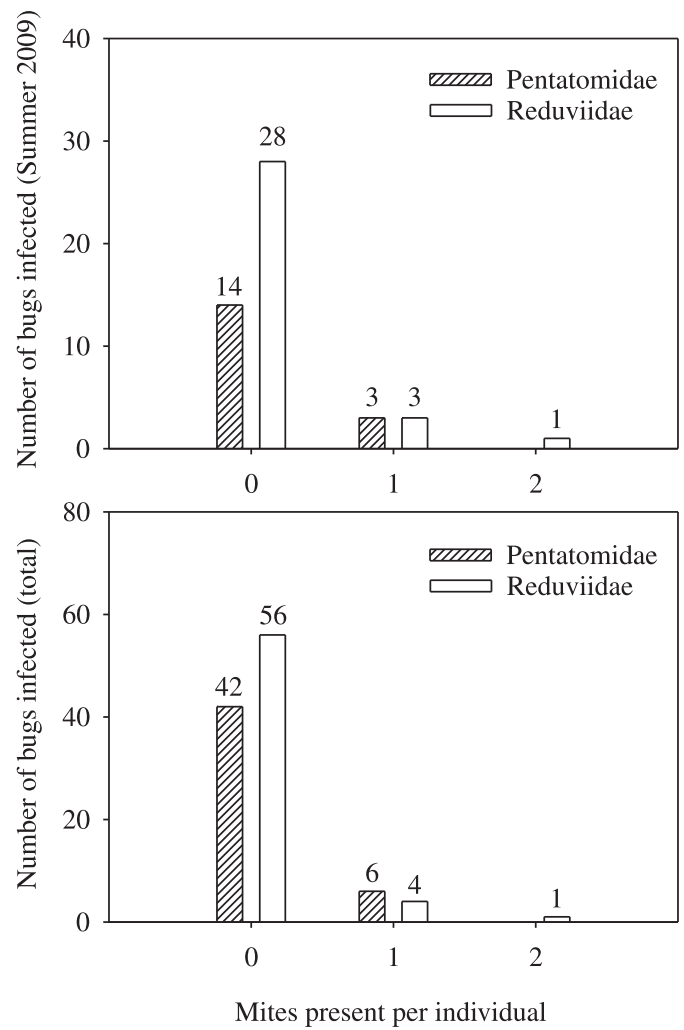

Figure 1. Frequency distribution of Pentatomidae and Reduviidae hosts with different numbers of larval erythraeid mites attached in the summers of 2007, 2008 and 2009.

Table 1. Number of Heteroptera adults (and nymphs*) collected by sweeping vegetation in the summers of 2007, 2008 and 2009 in a secondary forest in Viçosa, Minas Gerais State, Brazil.

\begin{tabular}{lccc}
\hline Genus & \multicolumn{1}{c}{ Seasons } & Summer 2009 \\
\cline { 2 - 4 } (Feduviidae) & Summer 2007 & Summer 2008 & 18 \\
Heza sp. & 3 & 7 & 9 \\
Apiomerus sp. & 5 & 7 & 5 \\
Harpactor angulosus & 2 & 2 & - \\
Arilus sp. & 1 & 2 & $1+3^{*}$ \\
(Pentatomidae) & & 3 & 4 \\
Edessa sp.1 & $5+4 *$ & 3 & 7 \\
Edessa sp. 2 & 11 & 2 & 2 \\
Podisus nigrispinus & 3 & - & 49 \\
Nezara sp. & - & 26 & \\
Total & 34 & & \\
\hline
\end{tabular}



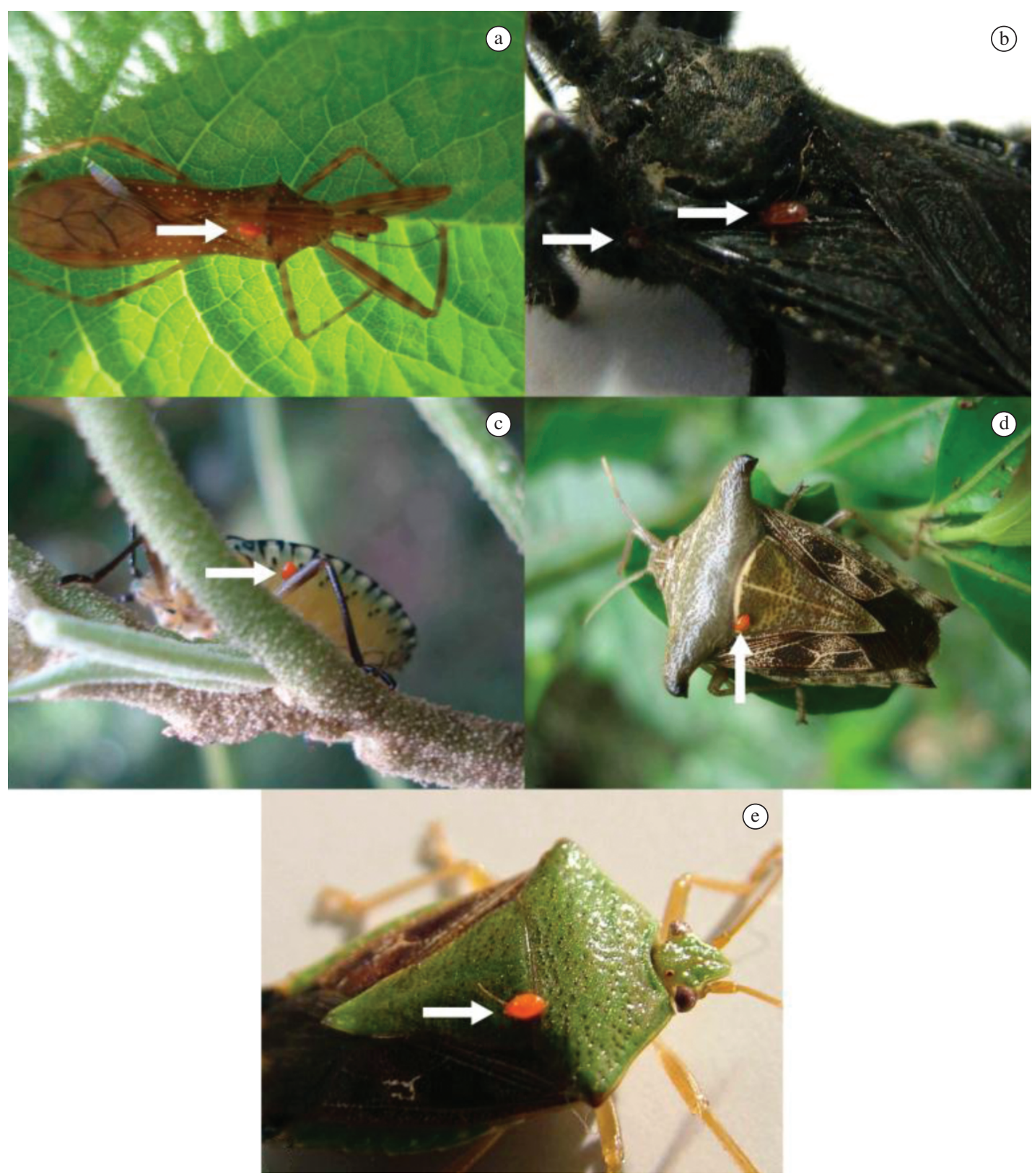

Figure 2. (1-5). Heteroptera species hosting the erythraeid mite Leptus sp. (indicated by the white arrow). 1) Heza sp.; 2) Apiomerus sp.; 3) Edessa sp.1 nymph; 3) Edessa sp.1 adult and 5) Edessa sp.2.

or after direct contact with xenobiotics (Boyd and Boethel, 1998) which may represent an indirect powerful tool against parasitism on the moment of attachment. This may be helpful to explain the attachment site preference of Leptus sp. on the dorsal side of the bugs, originating an ineffective defense from the host, but certainly it is not the only reason. The effective behavior of mites must also be taken into account because according to Eickwort (1990) the parasites have some means of escaping or tolerating the hygienic and defensive behaviors when they attach, for example, on social insects, such as bees, ants or termites. The attachment act by the mites in order to observe if bugs behavior might influence attachment site selection was difficult to observe in the field and could be studied in future work. Furthermore, the methodology used to rear the predatory bugs in our laboratory was not adequate to rear the erythraeid mite. All parasitized reduviid predators brought to the laboratory fed normally with no distinct differences in its behavior. No defensive attempts were also observed against the mites which is compatible with 
Âbro (1988) who reported that harvestmen adults ignored Leptus larvae, which is surprising in light of their frequent grooming. Baker (1982) did not cite any defensive behavior of coccinelid beetles hosting this erythraeid.

In the studied area, sampling programs have been conducted in a four-year-period for a wide range of insect taxa such as ichneumonids, symphyta, saturniid moths, chrysomelids, vespids, arctiid and nymphalid butterflies, bees, flies and others. Many of these are known as potential hosts (Eickwort, 1990; Southcott, 1993; Saboori and Ostovan, 2000; Haitlinger, 2009), but no interaction with Leptus was observed. Only a few species of Heteroptera appear to serve as alternative hosts for Leptus mites which inhabit the secondary forest with climatic conditions from Viçosa. Erythraeid mites are generalist parasites, but the reason why specific Heteroptera groups such as pentatomid and reduviid bugs were collected hosting this mite are unknown.

The mite parasitism capacity on the bugs was very low compared to other studies. Townsend et al. (2006) found values of mite parasitism up to $20.3 \%$ for Leptus mites having Leiobunum formosum (Opiliones: Sclerosomatidae) as hosts in southeastern Virginia in above ground habitats. Parasitism of this erythaeid mite varied from 2.4 to 4.3 in the chinch bug, Blissus antillus Leonard (Hemiptera: Lygaeidae), in pastures in Rio de Janeiro state, Brazil (Coracini and Samuels, 2002) and $0.51 \%$ of parasitism was observed by Miranda and Bermúdez (2008) in calliphorid flies by Macrochelidae, Erythraeidae and Histiostomatidae mites in Panamá. Townsend et al. (2008) showed a prevalence of infestation of $9.9 \%$ of this mite group parasitizing harvestmen from the Cranaidae and Manaosbiidae families. The very low rates of parasitism found in this study may be related to the foraging behavior of pentatomid and reduviid bugs not always occupying leaf litter areas where parasitic mites are generally found (Southcott, 1961) or by seasonal variation in the life history of the parasite, which according to Townsend et al. (2006) may simply reflect periods in the year when larval mites are particularly common or are relatively rare. MacKay et al. (1992) also related a considerable variability in the parasitism by Leptus sp. larvae on Trachyrhinus marmoratus (Arachnida: Opiliones) supposing that the development of the mite may be synchronized with the host.

For some insects, this specific host-parasite relation showed no measurable adverse effects upon the reproduction or survival of hosts (Eickwort, 1990) or, paradoxically, adverse impacts on individual fitness (Polak and Markow, 1995). Beneficial interactions must not be discarded such as that reported by Eickwort (1979), who described that solitary halictids have evolved special structures to carry the phoretic histiostomatid deutonymphs with sanitary holes removing potentially harmful bacteria from host bodies and provisions. The importance for Leptus mites attaching on such bugs is, at the moment, a matter of conjecture because the ecology of most which use insects as a food source is unknown and, in some cases, mite species are only known from the hypopal stage.
This survey revealed an interesting association between terrestrial bugs and mites, which leads to the conclusion that the interactions between Leptus mites and insects are likely to be far more diverse than previously realized.

Acknowledgements - We would like to thank C. Welbourn (USDA) for helpful comments about the identification of mite specimens. We appreciate the help of "Conselho Nacional de Desenvolvimento Científico e Tecnológico (CNPq)" and "Fundação de Amparo à Pesquisa do Estado de Minas Gerais (FAPEMIG)" for the financial support.

\section{References}

ÂBRO, A., 1988. The mode of attachment of mite (Leptus spp.) to harvestmen (Opiliones). Journal of Natural History, vol. 22, p. 123-130. http://dx.doi.org/10.1080/00222938800770091

ARILLO, A., 2007. Paleoethology: Fossilized behaviours in amber. Geologica Acta, vol. 5, p. 159-166.

ARMAS, LF. and PIETRO TRUEBA, D., 2003. Primer registro de ácaros parásitos de Amblipígidos (Arachnida: Amblypygi). Revista Ibérica de Aracnología, vol. 7, p. 133-134.

BAKER, GT., 1982. Site attachment of a protelean parasite (Erythraeidae: Leptus sp.). Experientia, vol. 38, p. 923. http:// dx.doi.org/10.1007/BF01953655

BAKER, AS. and SELDEN, PA., 1997. New morphological and host data for the ectoparasitic larva of Leptushidakai Kawashima (Acari, Acariformes, Erythraeidae). Systematic Parasitology, vol. 36, p. 183-191. http://dx.doi.org/10.1023/A:1005757014689

BOYD, ML. and BOETHEL, DJ., 1998. Residual toxicity of selected insecticides to heteropteran predaceous species (Heteroptera: Lygaeidae, Nabidae, Pentatomidae) on soybean. Environmental Entomology, vol. 27, p. 154-160.

COKENDOLPHER, JC., 1993. Pathogens and parasites of Opiliones (Arthropoda: Arachnida). Journal of Arachnology, vol. 21, p. 120-146.

CORACINI, DLA. and SAMUELS, RI., 2002. Natural enemies of the chinch bug, Blissusantillus Leonard (Hemiptera: Lygaeidae: Blissinae), pasture pest in Rio de Janeiro state, Brazil. Neotropical Entomology, vol. 31, p. 165-167. http://dx.doi.org/10.1590/ S1519-566X2002000100024

EICKWORT, GC., 1979. Mites associated with sweat bees (Halictidae). In RODRIGUEZ, JG. (Orgs.). Recent Advances in Acarology. New York: Academic. p. 575-581.

-, 1990. Associations of mites with social insects. Annual review of Entomology, vol. 35, p. 469-488. http://dx.doi.org/10.1146/ annurev.en.35.010190.002345

FLETCHTMANN, CHW., 1980. Doisácaros associados a abelha Apis mellifera L. no Peru. Anais da Escola Superior de Agricultura “Luiz de Queiroz”, vol. 37, p. 737-741.

HAITLINGER, R., 1993. Larval Leptus ectoparasitic on tenebrionid beetles from Ghana. Bollettino della Societa Entomologica Italiana, vol. 125, p. 166-170.

-, 1999. Four new species of Leptus Latreille, 1796 (Acari, Prostigmata, Erythraeidae) from Peru. Museo Regionale di Scienze Naturali Bollettino (Turin), vol. 17, p. 149-162. 
-, 2009. Four new species of Leptus Latreille, 1796 (Acari: Prostigmata: Erythraeidae) from the Canary Islands. Systematic \& Applied Acarology, vol. 14, p. 140-152.

LAPOLA, DM. and FOWLER, HG. 2008. Questioning the implementation of habitat corridors: a case study in interior São Paulo using ants as bioindicators. Brazilian Journal of Biology, vol. 68, p. 11-20. PMid:18470373.

LEMOS, WP., ZANUNCIO, JC. and SERRÃO, JE., 2005. Attack behavior of Podisus rostralis (Heteroptera: Pentatomidade) adults on caterpillars of Bombyx mori (Lepidoptera: Bombycidae). Brazilian Archives of Biology and Technology, vol. 48, p. 975-981. http:// dx.doi.org/10.1590/S1516-89132005000800014

MACKAY, WP., GRIMSLEY, C. and COKENDOLPHER, JC., 1992. Seasonal changes in a population of desert harvestmen, Trachyrhinus marmoratus (Arachnida: Opiliones), from Western Texas. Pysche, vol. 99, p. 207-213. http://dx.doi.org/10.1155/1992/90348

MARANGON, LC., SOARES, JJ. and FELICIANO, ALP., 2003. Florística arbórea da Mata da Pedreira, município de Viçosa, Minas Gerais. Revista Árvore, vol. 27, p. 207-215. http://dx.doi. org/10.1590/S0100-67622003000200010

McALONN, FM. and DURDEN, LA., 2000. Attachment sites and frequency distribution of erythraeid mites, Leptusindianensis (Acari: Prostigmata), ectoparasitic on harvestmen, Leiobunum formosum (Opiliones). Experimental and Applied Acarology, vol. 24, p. 561-567. http://dx.doi.org/10.1023/A:1026554308826

MIRANDA, R. and BERMÚDEZ, S., 2008. Ácaros (Arachnida: Acari) asociados con moscas Calliphoridae (Diptera: Oestroidea) em tres localidades de Panamá. Revista Colombiana de Entomología, vol. 34, p. 192-196.

POLAK, M. and MARKOW, TA., 1995. Effect of ectoparasitic mites on sexual selection in a Sonoran Desert fruit fly. Evolution, vol. 49, p. 660-669. http://dx.doi.org/10.2307/2410319

REIS, MA., ZANETTI, R., SCOLFORO, JRS., FERREIRA MZ. and ZANUNCIO, JC., 2008. Sampling of leaf-cuting ant nests (Hymenoptera: Formicidae) in eucalyptus plantations using quadrant and prodan methods. Sociobiology, vol. 51, p. 21-29.

SABOORI, A. and OSTOVAN, H., 2000. A new species of the genus Leptus Latreille, 1796 (Acari: Erythraeidae) ectoparasitic on sun pest, Eurygaster integriceps Puton (Hemiptera: Scutelleridae) from Iran. Systematic \& Applied Acarology, vol. 5, p. 143-147.
SOUTHCOTT, RV., 1961. Studies on the systematics and biology of the Erythraeoidea (Acarina), with a critical revision of the genera and subfamilies. Australian Journal of Zoology, vol. 9, p. 367-611. http://dx.doi.org/10.1071/ZO9610367

-, 1991. Descriptions of larval Leptus (Acarina: Erythraeidae) ectoparasitic on Australian diptera, and two earlier described Australian larvae. Invertebrate Taxonomy, vol. 5, p. 717-763. http://dx.doi.org/10.1071/IT9910717

-, 1992. Revision of the larvae of Leptus Latreille (Acarina: Erythraeidae) of Europe and North America, with descriptions of post-larval instars. Zoological Journal of the Linnean Society, vol. 105, p. 1-153. http://dx.doi.org/10.1111/j.1096-3642.1992. tb01228.x

-, 1993. Larvae of Leptus (Acarina: Erythraeidae) ectoparasitic on higher insects of Australia and New Guinea. Invertebrate Taxonomy, vol. 7, p. 1473-1550. http://dx.doi.org/10.1071/IT9931473

-, 2008. Larvae of Leptus (Acarina: Erythraeidae), free-living or ectoparasitic on arachnids and lower insects of Australia and Papua New Guinea, with descriptions of reared post-larval instars. Zoological Journal of the Linnean Society, vol. 127: p. 113-276.

TOWNSEND JUNIOR, VR., MULHOLLAND, KA., BRADFORD, JO., PROUD, DN. and PARENT, KM., 2006. Seasonal variation in parasitism by erythraeid mites (Leptus sp.) upon the harvestmen Leiobunum formosum (Opiliones, Sclerosomatidae). Journal of Arachnology, vol. 34, p. 492-494.

TOWNSEND JUNIOR, VR., PROUD, DN., MOORE, MK., TIBBETTS, JA., BURNS, JA., HUNTER, RK., LAZAROWITZ SR. and FELGENHAUER, BE., 2008. Parasitic phoretic mites associated with Neotropical harvestmen from Trinidad, West Indies. Annals of the Entomological Society of America, vol. 101, p. 1026-1032. http://dx.doi.org/10.1603/0013-8746-101.6.1026

WENDT, FE., OLOMSKI, R., LEIMANN, J. and WOHLTMANN, A., 1992. Parasitism, life cycle and phenology of Leptus trimaculatus (Hermann, 1804) (Acari: Parasitengonae: Erythraeidae) including a description of the larvae. Acarologia, vol. 33, p. 55-68.

ZANUNCIO, JC., LOPES, ET., LEITE, HG., ZANETTI, R., SEDIYAMA, CS. and FIALHO, MCQ., 2004. Sampling methods for monitoring the number area of colonies of leaf cutting ants (Hymenoptera: Formicidae) in Eucalyptus plantations in Brazil. Sociobiology, vol. 44, p. 337-344. 